\title{
Who Are China's Entrepreneurs?
}

\author{
Simeon Djankov* \\ Yingyi Qian \\ Gérard Roland \\ Ekaterina Zhuravskaya
}

October 2005

\section{Very preliminary draft for NBER workshop. Please do not circulate or quote.}

\begin{abstract}
Social scientists studying the determinants of entrepreneurship have emphasized three distinct perspectives: the role of institutions, the role of social networks and the role of personal characteristics. We conduct a survey from five large developing and transition economies to better understand entrepreneurship in view of these three perspectives. Using data from a pilot study with over 2,000 interviews in 7 cities across China, we find that compared to non entrepreneurs, entrepreneurs are much more likely to have family members who are entrepreneurs as well as childhood friends who became entrepreneurs, suggesting that social networks play an important role in entrepreneurship. Entrepreneurs also differ strongly from non entrepreneurs in their attitudes towards risk and their work-leisure preferences.
\end{abstract}

\footnotetext{
${ }^{*}$ The authors are at the World Bank, UC Berkeley and NBER, UC Berkeley and CEPR, UC Berkeley and CEPR, CEFIR and CEPR, respectively. We thank Xiaolu Wang and Irina Levina for excellent research assistance, and the International Finance Corporation for financial support.
} 


\section{Introduction.}

It has been increasingly recognized that entrepreneurship plays a crucial role in successful economies. The Schumpeterian approach to growth (Aghion and Howitt, 1997) advances the view that entrepreneurial dynamism is the key to innovation and growth. A growing body of research also emphasizes the role of entrepreneurs and the development of a vibrant small and medium enterprise sector in the process of economic development (World Bank, 2003). Understanding the factors that enable and hinder entrepreneurial activities is thus at the heart of this research agenda.

Paradoxically, entrepreneurship is an underresearched topic in the social sciences - and especially in economics. It was not always so. Schumpeter (1934) discusses the role of the entrepreneur in the process of economic development at length. He imagines the entrepreneur as a creative, driven individual who finds "new combinations of [factors] of production” to develop a new product, corner a new market, or design a new technology. Schumpeter speculates about the psyche of the archetypal entrepreneur: he is motivated by a "dream to find a private kingdom, or dynasty... [driven by] the impulse to fight, to prove oneself superior to others, to succeed for the sake of...success itself”.

In mainstream economics however, entrepreneurship has never played a central role. For decades, the main focus of economics has been on the allocation of resources and how it is achieved by markets or by governments. It is only recently with the revival of interest in the question of economic growth that Schumpeter's views have acquired greater salience. . Empirical research on entrepreneurship in economics is surprisingly limited ${ }^{1}$.

In a broad sense, there are three distinct perspectives on entrepreneurship in the social sciences. The first is the institutional perspective emphasized by economists and political economists. This perspective focuses on the role of economic, political, and legal institutions in fostering or restricting entrepreneurship in different countries at various times. Particularly relevant institutional constraints are seen in two aspects. One aspect has to do with the credit market in financing entrepreneurial activities. For example, a major body of research in economic development has emphasized the role of credit constraints making it impossible for the poor to borrow to set up their own businesses (Banerjee and Newman, 1993). Another aspect has to do with security of property rights in providing the right incentives for entrepreneurs. For instance, the literature on transition from socialism to capitalism has emphasized the importance

\footnotetext{
${ }^{1}$ There exists a large literature on enterpreneurship in the management literature devoted mostly to advanced industrialized countries but it often lacks both theory and rigorous empirical analysis
} 
of institutions securing property rights (see e.g., Johnson, McMillan and Woodruff, 2002; McMillan and Woodruff, 2001; Roland, 2000, Che and Qian, 1998) and the nefarious role of predatory behavior by government bureaucrats (Djankov et al., 2002), and organized crime (Frye and Zhuravskaya, 2000, Roland and Verdier, 2003). Security of property rights is also an increasingly important theme in the development literature (Acemoglu et al., 2002; De Soto, 2000; Besley, 1995).

The second perspective focuses on the sociological variables that are shaping entrepreneurship. Sociologists have long emphasized the role of values (Cochran, 1971) and social networks (Young, 1971) in promoting or discouraging entrepreneurial activities. Social networks may work through a variety of channels, such as family, relatives, friends, or social groups in general.

The third perspective on entrepreneurship emphasizes individual characteristics of entrepreneurs. For example, psychologists have hypothesized about the psychological traits associated with entrepreneurs - such as a personal need for achievement (McClellan, 1961), belief in the effect of personal effort on outcomes (McGhee and Crandall, 1968; Lao, 1970), attitudes towards risk, and individual self-confidence (Liles, 1974). Personal characteristics of entrepreneurs is also a major theme of a recent work of Lazear (2002), who used the survey data of Stanford University MBA graduates and found that those with a higher number of jobs and shorter job tenures before graduate school were most likely to become entrepreneurs afterwards. He concludes that individuals who become entrepreneurs have a special ability to acquire general skills, which they then apply to their own businesses.

The current project studies entrepreneurship from all these three perspectives using a new data set to be collected from several developing countries, including some countries in transition from socialism. Our general plan is to conduct surveys in five large developing countries located in all major continents--Brazil, Russia, India, Nigeria, and China, or BRINC for short . There are several reasons why we chose to study entrepreneurship in these countries. First, they are among the largest emerging economies in the world and are located in all major continents. In particular, Brazil, Russia, India and China are currently perceived as the world's major growth engines for the coming decades. Second, entrepreneurship is only emerging in transition economies (and it is very unequally developed in developing countries) so we are able to observe out of steady state phenomena and have a glimpse at the development of entrepreneurship. From that perspective, the study of entrepreneurship in those countries might be more revealing than if conducted in advanced industrialized countries where the development of entrepreneurship has 
generally been more successful, is more in steady state and exhibits less variation. Third, because these are large countries, we are able to exploit substantial regional variation in institutions and culture within those countries. Identical questions asked across the different countries also allow us to ease cross-country comparisons and to draw broad conclusions for developing countries as a whole.

Our surveys cover both entrepreneurs and non-entrepreneurs in order to understand how these groups differ in terms of their individual characteristics, skills, education, intellectual and personality traits, family background, social origins, social networks, values and beliefs, and in their perception of the institutional, social and economic environment businesses face.

We report in this paper some initial observations from a pilot survey conducted in China in 2003-2004.

What are the main results from this pilot study? Interestingly, we find suggestive evidence that social network effects play a very large role in determining entrepreneurial behavior: those individuals whose relatives and childhood friends are entrepreneurs are more likely to be entrepreneurs - although this result should be interpreted with caution due to the likelihood of well-known omitted variable biases in the estimation of social effects (see Manski, 1993). Finally, individual characteristics as greed, and willingness to take risks are also important determinants of entrepreneurship, echoing the claims of Schumpeter and others. These preliminary findings are similar to those found in our pilot study of Russia (Djankov et al, 2005) where we also found that social networks played an important role.

The rest of the paper is organized as follows. Section 2 describes the survey data collection. Section 3 presents summary statistics on the differences between entrepreneurs and non-entrepreneurs in Russia. Section 4 reports probit and logit analysis on variables associated to entrepreneurship. Section 5 concludes.

\section{The survey.}

The pilot study was performed in Beijing and six other cities in three different regions of China in Wuhan and Huanghi in Hubei Province; in Guangzhou and Zhongshan in Guangdong Province; and in Xi'An and Baoji in Shaanxi Province.

Three surveys were conducted. We first surveyed a random sample of 414 entrepreneurs 50-53 in each of the six regional cities and 108 from Beijing in the fall of 2004. An entrepreneur was defined as the owner or co-owner of a business with five or more employees. 
Early 2005, an additional 454 non-entrepreneurs - from 53 to 59 in each of the smaller size cities, and 116 in Beijing - were interviewed using a similar survey instrument Respondents were chosen randomly conditional on matching the age, gender and educational attainment of entrepreneurs from the first survey. In other words, the proportion of men, women, people at various ages and with different levels of educational attainment are near-identical in the two surveys. We opted for this approach to ensure that broad demographic differences between entrepreneurs and non-entrepreneurs were not driving the results, but rather other factors. In addition to the non-entrepreneurs "matched" to the demographic characteristics of the entrepreneurs, 107 additional non-entrepreneurs were also surveyed without regard to there demographic characteristics (from 19 to 13 in each of the six cities and 17 in Beijing).

Finally, a short survey was run among a random sample of 1275 respondents (with the same breakdown across cities) asking nine questions about their personal characteristics, including whether or not they are an entrepreneur or self-employed. This data allow us to roughly determine the proportion of entrepreneurs across the study sites. In all of the empirical analysis, the observations are weighted with weights equal to the inverse of the probability for a particular respondent (entrepreneur or non entrepreneur) to get into our sample. The weights reflect differences in entrepreneurship, age, gender, and education across cities in the population, as well as the city size.

The limited number of cities and regions in the pilot study makes it difficult to generalize about the impact of regional institutional and cultural differences on entrepreneurship.

\section{How do entrepreneurs compare to non-entrepreneurs?}

Table 1 lists means for a number of variables for entrepreneurs and non entrepreneurs. For the latter, we use conditional means controlling for age, gender, education and city dummies. ${ }^{2}$ In terms of individual characteristics, the major difference that stands out is the difference in the willingness to accept a risk neutral gamble: accept either 1) win $\$ 10$ with probability $1 / 2$ and lose $\$ 10$ with probability $1 / 2$ or 2 ) win $\$ 20$ with probability $1 / 2$ and lose $\$ 20$ with probability $1 / 2-90 \%$ of entrepreneurs in China responded yes (compared to 57\% of non entrepreneurs). There is thus more than a $30 \%$ difference in response between both groups. We do not find important differences in either cognitive scores or excellence in education. Intriguingly, only $29 \%$ of entrepreneurs

\footnotetext{
${ }^{2}$ It is important to note that all the main results from the comparison of means are robust to adding a control for current wealth of the individual.
} 
mentioned they engaged in sports against $81 \%$ for non entrepreneurs. Entrepreneurs view themselves as richer than average and this is also reflected in their consumption patterns; they spend less of their income on food, own more consumer durables and are more likely to own a car.

\section{INSERT TABLE 1}

In terms of their family background, the parents of entrepreneurs do not have a higher education than non entrepreneurs but they were more likely to have been bosses or directors and were richer than average. Interestingly while fathers of entrepreneurs were not more likely to have been members of the communist party, mothers were less likely to have been party members. A very important difference between entrepreneurs and non entrepreneurs relates to the number of entrepreneurs in one's family or among one's childhood friends. Entrepreneurs have nearly three times more entrepreneurs in their family (parents, aunts or uncles, siblings and cousins) than non entrepreneurs. Respondents were asked to name five friends from their childhood and adolescence, and then to report how many of these five have become entrepreneurs. The difference in response for entrepreneurs and non entrepreneurs is striking: the answer is .84 for childhood friends and 1.265 for adolescence friends among entrepreneurs compared to .55 and .44 for non entrepreneurs.

Entrepreneurs differ also in terms of labor-leisure preferences. Respondents were asked whether they would retire if they received a windfall income of 100 or 500 or 5000 times the annual GDP per capita of the country. Entrepreneurs were much less likely to respond positively than non entrepreneurs. The main reason is that entrepreneurs want to earn more money $(70 \%$ of those who did not want to retire if earning above 5000 times GDP per capita mentioned it as a motivation against $43 \%$ for non entrepreneurs who would not retire for the same amount). Among other motivations, entrepreneurs do not believe that their work serves a useful purpose compared to non entrepreneurs but work satisfaction was cited as a motive by about three quarter of all respondents, whether entrepreneurs or not. While entrepreneurs do not perceive themselves happier (92\% against 91\%), they consider that they are successful in life (64\% against 43\%).

Respondents were asked questions about values and beliefs. We do not see big differences with two important exceptions. Work is more important for entrepreneurs (80\% against 63\%) and they value political freedom much more (73\% compared to $28 \%$ for non entrepreneurs). Answers to questions about social norms differ in some respects. Entrepreneurs consider bribing more justifiable. Intriguingly, they consider shirking at work more justifiable and wrongly think that other people think likewise. Questions on trust did not deliver many different answers except for the - perhaps not surprising- result that entrepreneurs place more trust in other businessmen and their subordinates. 
Questions on the individual perceptions of institutional environment were also asked. Interestingly, controlling for city-level differences, entrepreneurs have a more positive perception of local government's attitude towards entrepreneurs than non entrepreneurs but this is reversed when it comes to the central government. Note however that about $80 \%$ of entrepreneurs consider that different levels of government are favorable towards entrepreneurs. Entrepreneurs would also be more likely to go to court if abused by a government official. This reveals that entrepreneurs perceive in general government to be favorable towards entrepreneurship. If institutional environment is the same for all (potential) firms in each city, this could be interpreted as evidence of the importance of perceptions for the choice to become an entrepreneur: those who have lower perceptions, chose not go into entrepreneurship since we control for city-level variation. If, however, there is a cross-sectional variation in institutional environment within cities, the fact that non entrepreneurs perceive institutional environment to be worse may just be a consequence of it being actually worse for these individuals: those who faced less favorable institutional environment just could not start their business. Interestingly, on perceptions of crime levels, when asked if business people are subject to theft of property, one has less positive answers among entrepreneurs.

We also asked questions related to problems in doing business. In general, non entrepreneurs responded less pessimistically than non entrepreneurs. The most serious problems cited by entrepreneurs is the difficulty of raising outside finance (mentioned by 25\%) followed by non transparent rules of the game (21\%), government regulations (19\%) and corruption (17\%).

To summarize this section, the main differences we found between entrepreneurs and non entrepreneurs is that entrepreneurs are more willing to take risks, have more entrepreneurs in their family and among childhood friends, value work highly and have high wealth aspirations. They also have in general a more positive opinion of local government's attitude towards entrepreneurs.

\section{Determinants of entrepreneurship and business expansion}

To understand the determinants of entrepreneurship, we focus on variables that can plausibly be considered exogenous to the decision to become an entrepreneur.

\section{INSERT TABLE 2}

The first three columns of Table 2 present some multivariate probit regressions where the dependent variable takes a value of 1 if the respondent is an entrepreneur and 0 otherwise. We 
find again that the social network variables (having family members and childhood friends as entrepreneurs) are strongly associated with entrepreneurship. Making a causal claim about the effect of social interactions using cross-sectional survey data of this sort is problematic because of the likely omitted variables (for instance, external factors that influence various members of a social group), as discussed by Manski (1993) and others. So we should interpret the results cautiously and do not claim more than a robust correlation at this stage. Note that risk-loving and greed also come out significant. Having a mother member of the communist party has a significant negative effect in columns 1 and 3. Note also the positive coefficient on height. In column 4, we use the number of years as entrepreneur as a dependent variable. We find essentially the same variables playing a significant role except that the father having a higher education enters positively and the experience as entrepreneur is negatively associated to the perceived attitude of government towards entrepreneurs.

Interestingly, the surveys we did among non entrepreneurs allowed us to sample former entrepreneurs and people who thought about becoming an entrepreneur but in the end decided not to do so. Note that in both cases, while social network variables remain significant (family entrepreneurs were not significant for failed entrepreneurs though), greed and risk-taking are not significant. This could suggest that social networks have an effect on the decision to become entrepreneur but that risk-taking and greed are necessary for success and drive. Another reason why these regressions are interesting is that one might fear that the friend entrepreneur variable is endogenous since entrepreneurs who are in frequent contact with other entrepreneurs might first remember their entrepreneur friends. The positive coefficient of that variable in the regression for former entrepreneurs is reassuring from that point of view since their memory is less likely to be biased.

\section{INSERT TABLE 3}

Another issue is that there are different types of business owners who became entrepreneurs due to varying circumstances. We asked respondents questions about those circumstances. The two major categories that come out are what we call entrepreneur by opportunity and entrepreneur by necessity. The former became business owners because they seized a business opportunity. They are the true entrepreneurs in the Schumpeterian sense. The latter became business owners primarily because they lost their job or because of economic decline in their previous sector. Note that other motives for becoming entrepreneur such as having obtained money play a relatively minor role in the response to that question. Table 3 reports probit analysis as well as multinomial logit on these two different types of business owners. The results 
are pretty much the same as for entrepreneurs in general with a few exceptions. Family is not significant for entrepreneurs by opportunity. The main variables are friends, risk-loving and greed. For entrepreneurs by necessity, the family variable is significant and the higher education of the father has a negative coefficient.

\section{INSERT TABLE 4}

Table 4 looks at sales growth of entrepreneurs' firms. Column 1 presents the results of a probit regression for those entrepreneurs who had a positive sales growth and the next three columns are simple OLS regressions of a discrete variable that equals 1 if past year's sales growth was below 0\%, 2 if it was between 0 and 5\%, 3 if it was between 6 and 10\%, 4 if 11$20 \%, 5$ if growth was above $20 \%$ on a number of dependent variables. Apart from the variables used in previous tables, we also control for the sector and for size of business, measured by the $\log$ number of employees. We see that the family entrepreneur variable comes out significantly positive in all regressions. This is interesting because it shows not only that family matters for the choice to become an entrepreneur but also for enterprise expansion. The current survey instrument does not permit to find out the precise channels through which family matters. Family might influence values, transmit idiosyncratic skills for entrepreneurship, provide moral encouragement but also money to start one’s enterprise and expand it.

\section{INSERT TABLE 5}

Table 5 takes a more direct look at the sources of financing of entrepreneurs and the obstacles to become an entrepreneur. We see from Table 5a that the main source of financing for both startups and expansion of firms is retained earnings (respectively $57 \%$ for the former and $70 \%$ for the latter). Loans or investments from relatives play a role only for $12 \%$ of startups and $5 \%$ of expansions and loans from friends account for $6 \%$ of startups and only $4 \%$ of expansions. Note that while bank credit accounts for only $4 \%$ of startups, it finances $13 \%$ of expansions. This suggests strongly that liquidity constraints play a big role at the startup level. Table 5b asks about the main reason those who seriously thought of becoming an entrepreneur chose not to do so. By far the most important reason that comes up is that they did not find the money (58\%). Only 14\% responded that they did not find a good project and 12\% that too much risk was involved. In Table 5c, we asked non entrepreneurs why they never thought of becoming an entrepreneur. The most important reason mentioned is that they would not be able to find the money (29\%) but it is closely followed by "Do not have the appropriate skills" (24\%) and "Satisfied with current job" (21\%). So, liquidity constraints seem to play an important role for those who seriously considered becoming an entrepreneur and only one among others for other respondents. 


\section{Conclusions}

Preliminary results suggest that the determinants of entrepreneurship in China are multiple. Chinese entrepreneurs like to take risks and are greedy. Social network effects - having entrepreneurs in the family and among one's friends - appear important for the choice to become an entrepreneur. Cultural differences do not seem to play a key role, even though there are some notable differences between entrepreneurs and non-entrepreneurs, including their self-expressed work ethic. Credit constraints appear to play an important role in discouraging people from starting or expanding an enterprise but they are only one factor among others.

The current survey does not allow to differentiate the precise channels through which social network effects influence the choice to become an entrepreneur. Are there hidden characteristics in entrepreneurial families that create a sorting effect to create clusters of social networks of entrepreneurs? Are there peer effects - or simply reflects social sorting? To the extent that there are network effects, what are these about? Do they merely alleviate credit constraints? Do they serve as encouragement and create herding effects? Are they the locus of exchange of business information and skills that have significant value for entrepreneurs? We are refining our survey to give a better answer to those questions. In addition, the data from the Chinese pilot alone are insufficient to evaluate the effect of institutional variables on entrepreneurship because of too few town-level observations. One of the tasks of the larger survey is to compare the importance of individual and institutional effects. 
References

Acemoglu, D. J Robinson and S. Johnson (2001) "The Colonial Origins of Comparative Development: An Empirical Investigation”, American Economic Review, volume 91, pp. 1369-1401.

Aghion, Ph. And P. Howitt (1997) Endogenous Growth Theory, MIT Press, Cambridge Massachussetts.

Banerjee, A. and A. Newman (1993) "Occupational Choice and the Process of Development" Journal of Political Economy, 101(2).

Besley, T. (1995). "Property Rights and Investment Incentives: Theory and Evidence from Ghana," Journal of Political Economy, Vol. 103 (5) pp. 903-37

Che, J. and Y. Qian (1998) "Insecure Property Rights and Government Ownership of Firms," Quarterly Journal of Economics, May, 113(2), pp. 467-496.

Cochran, T. (1971) “The Entrepreneur in Economic Change”, in Entrepreneurship and Economic Development, The Free Press.

De Soto, H. (2000) The Mystery of Capital: Why Capitalism Triumphs in the West and Fails Everywhere Else, Harper \& Row.

Djankov, S. R. La Porta, F. Lopez de Silanez and A. Shleifer (2002) “The Regulation of Entry” Quarterly Journal of Economics, 1-37.

Djankov, S., E. Miguel, Y. Qian and E. Zhuravskaya (2005)“Who are Russia’s Entrepreneurs?”, Journal of the Euopean Economic Association.

Frye, T. and E. Zhuravskaya (2000) "Rackets, Regulation and the Rule of Law," Journal of Law, Economics, and Organization, Vol. 16 (2) pp. 478-502.

Johnson, S., J. McMillan and C. Woodruff, (2002) "Property Rights and Finance," American Economic Review, 92 (5) pp. 1335-1356.

Lao, R.C. (1970) "Internal-External Control and Competent and Innovative Behavior among Negro College Students”, Journal of Personality and Social Psychology.

Liles, P.R. (1971) New Business Ventures and The Entrepreneur, Richard D. Irwin.

McClelland, D. (1961), The Achieving Society, Princeton: D. Van Nostrand.

McGhee, P.E and V.C. Crandall. (1968) "Beliefs in Internal-External Control of Reinforcement and Academic Performance”, Child Development. 
Roland, G. (2000) Transition and Economics. Politis, Markets and Firms. MIT Press, Cambridge Massachusetts.

Roland, G. and T. Verdier (2003) "Law Enforcement and Transition”, European Economic Review.

World Bank, (2003) Doing Business in 2004: Understanding Regulation, Oxford University Press.

Young, Frank W. (1971) “A Macrosociological Interpretation of Entrepreneurship”, in Entrepreneurship and Economic Development, The Free Press. 
Table 1. Entrepreneurs compared to non entrepreneurs in China.

\begin{tabular}{|c|c|c|c|c|c|}
\hline \multirow[b]{2}{*}{ Individual Characteristics: } & $\begin{array}{l}\text { Entrepre- } \\
\text { neurs } \\
\text { Mean }\end{array}$ & $\begin{array}{l}\text { Non-entrepre } \\
\text { neurs } \\
\text { Conditional } \\
\text { mean }\end{array}$ & $\begin{array}{l}\text { SE for difference } \\
\text { in means }\end{array}$ & \multicolumn{2}{|c|}{$\begin{array}{l}\text { p-value for } \\
\text { difference in } \\
\text { means }\end{array}$} \\
\hline & & & & & \\
\hline Height, cm & 169.04 & 168.22 & 0.25 & 0.02 & $* *$ \\
\hline Number of localities lived & 1.85 & 1.55 & 0.18 & 0.15 & \\
\hline Number of distinct professional activities & 2.40 & 2.13 & 0.21 & 0.24 & \\
\hline $\begin{array}{l}\text { Number of industries respondent worked } \\
\text { in }\end{array}$ & 1.85 & 1.58 & 0.06 & 0.00 & $* * *$ \\
\hline Plan to move, \% & 0.04 & 0.11 & 0.04 & 0.09 & * \\
\hline Religious believer, \% & 0.12 & 0.08 & 0.02 & 0.09 & $*$ \\
\hline Married, \% & 0.84 & 0.80 & 0.06 & 0.53 & \\
\hline Speak foreign language, \% & 0.35 & 0.49 & 0.11 & 0.22 & \\
\hline Accept a risk neutral gamble, \% & 0.90 & 0.57 & 0.09 & 0.01 & $* * *$ \\
\hline Good health, self described, \% & 0.51 & 0.37 & 0.07 & 0.09 & $*$ \\
\hline Go in for sports, \% & 0.29 & 0.81 & 0.06 & 0.00 & $* * *$ \\
\hline Practice risky sports, \% & 0.12 & 0.10 & 0.03 & 0.62 & \\
\hline Overweight, \% & 0.20 & 0.15 & 0.05 & 0.38 & \\
\hline Cognitive text score & 3.92 & 3.80 & 0.26 & 0.64 & \\
\hline $\begin{array}{l}\text { Top } 10 \% \text { in secondary school (self } \\
\text { reported), \% }\end{array}$ & 0.37 & 0.38 & 0.05 & 0.82 & \\
\hline $\begin{array}{l}\text { Top } 10 \% \text { in high school, college or } \\
\text { university (self reported), } \% \\
\text { Income and Wealth: }\end{array}$ & 0.36 & 0.38 & 0.01 & 0.10 & \\
\hline Above average income (self assessed), \% & 0.50 & 0.11 & 0.02 & 0.00 & $* * *$ \\
\hline $\begin{array}{l}\text { Spend more than } 50 \% \text { of household } \\
\text { income on food, } \%\end{array}$ & 0.29 & 0.56 & 0.07 & 0.01 & $* * *$ \\
\hline Own a TV, \% & 1.00 & 1.00 & 0.00 & 0.34 & \\
\hline Own a satellite dish, \% & 0.11 & 0.06 & 0.05 & 0.31 & \\
\hline Own a microwave, $\%$ & 0.86 & 0.69 & 0.03 & 0.00 & $* * *$ \\
\hline Own a washing machine, $\%$ & 0.98 & 0.92 & 0.01 & 0.01 & $* * *$ \\
\hline Own a dishwasher, \% & 0.18 & 0.03 & 0.06 & 0.05 & $*$ \\
\hline Own a computer, \% & 0.85 & 0.63 & 0.10 & 0.07 & $*$ \\
\hline Own a car, \% & 0.56 & 0.19 & 0.12 & 0.03 & $* *$ \\
\hline Own an apartment, \% & 0.88 & 0.79 & 0.05 & 0.12 & \\
\hline Own a country house, $\%$ & 0.05 & 0.03 & 0.01 & 0.08 & * \\
\hline
\end{tabular}


Table 1 (continued)

\begin{tabular}{|c|c|c|c|c|c|}
\hline & $\begin{array}{c}\text { Entrepre- } \\
\text { neurs } \\
\text { Mean }\end{array}$ & $\begin{array}{c}\text { Non-entrepre } \\
\text { neurs } \\
\text { Conditional } \\
\text { mean }\end{array}$ & $\begin{array}{c}\text { SE for } \\
\text { difference } \\
\text { in means }\end{array}$ & \multicolumn{2}{|c|}{$\begin{array}{c}\mathrm{p} \text {-value } \\
\text { for } \\
\text { difference } \\
\text { in means }\end{array}$} \\
\hline \multicolumn{6}{|l|}{ Sociological Characteristics: } \\
\hline Father has secondary special or higher education, \% & 0.29 & 0.27 & 0.04 & 0.57 & \\
\hline Mother has secondary special or higher education, \% & 0.14 & 0.18 & 0.06 & 0.46 & \\
\hline Father was a boss or director, $\%$ & 0.30 & 0.13 & 0.05 & 0.02 & ** \\
\hline Mother was a boss or director, \% & 0.06 & 0.03 & 0.02 & 0.10 & \\
\hline $\begin{array}{l}\text { Father was a worker or employee without special education, } \\
\%\end{array}$ & 0.56 & 0.72 & 0.05 & 0.01 & $* *$ \\
\hline $\begin{array}{l}\text { Mother was a worker or employee without special } \\
\text { education, \% }\end{array}$ & 0.70 & 0.71 & 0.05 & 0.86 & \\
\hline Father was a member of the Communist party, \% & 0.40 & 0.31 & 0.10 & 0.42 & \\
\hline Mother was a member of the Communist party, \% & 0.10 & 0.15 & 0.01 & 0.01 & $* * *$ \\
\hline Parent wealth was above average when 16 years old, \% & 0.20 & 0.09 & 0.05 & 0.09 & $*$ \\
\hline Number of family members, who are entrepreneurs & 0.88 & 0.38 & 0.08 & 0.00 & $* * *$ \\
\hline Number of childhood friends, who became entrepreneurs & 0.84 & 0.55 & 0.14 & 0.09 & $*$ \\
\hline Number of adolescent friends, who became entrepreneurs & 1.26 & 0.44 & 0.21 & 0.01 & $* * *$ \\
\hline $\begin{array}{l}\text { Did experience of your friends from school influence your } \\
\text { career? \% }\end{array}$ & 0.41 & 0.08 & 0.03 & 0.00 & $* * *$ \\
\hline \multicolumn{6}{|l|}{ Motivation, Greed, Happiness: } \\
\hline Retire if won 100 times GDP per capita, \% & 0.05 & 0.24 & 0.06 & 0.02 & $* *$ \\
\hline Retire if won 500 times GDP per capita, \% & 0.14 & 0.37 & 0.03 & 0.00 & $* * *$ \\
\hline Retire if won 5000 times GDP per capita, \% & 0.31 & 0.44 & 0.05 & 0.05 & $*$ \\
\hline Not retire if won a large sum: I like what I do, \% & 0.74 & 0.75 & 0.08 & 0.93 & \\
\hline Not retire if won a large sum: I want more money, \% & 0.70 & 0.43 & 0.07 & 0.01 & $* * *$ \\
\hline $\begin{array}{l}\text { Not retire if won a large sum: my work serves useful social } \\
\text { purpose, \% }\end{array}$ & 0.18 & 0.81 & 0.08 & 0.00 & $* * *$ \\
\hline Very happy or quite happy in life, \% & 0.92 & 0.91 & 0.02 & 0.76 & \\
\hline Very successful or quite successful in life, \% & 0.64 & 0.43 & 0.06 & 0.01 & $* * *$ \\
\hline
\end{tabular}


Table 1 (continued)

\begin{tabular}{|c|c|c|c|c|c|}
\hline \multirow[t]{2}{*}{ Own Values: } & \multirow[t]{2}{*}{$\begin{array}{c}\text { Entrepre- } \\
\text { neurs } \\
\text { Mean }\end{array}$} & \multirow[t]{2}{*}{$\begin{array}{c}\text { Non- } \\
\text { entrepre } \\
\text { neurs } \\
\text { Conditional } \\
\text { mean }\end{array}$} & \multirow[t]{2}{*}{$\begin{array}{l}\text { SE for } \\
\text { difference } \\
\text { in means }\end{array}$} & \multicolumn{2}{|c|}{$\begin{array}{l}\text { p-value for } \\
\text { difference } \\
\text { in means }\end{array}$} \\
\hline & & & & & \\
\hline Friends are very important, \% & 0.60 & 0.66 & 0.04 & 0.16 & \\
\hline Relations with parents are very important, \% & 0.86 & 0.88 & 0.01 & 0.10 & * \\
\hline Education of children is very important, \% & 0.91 & 0.91 & 0.01 & 0.43 & \\
\hline Financial well-being is very important, \% & 0.73 & 0.62 & 0.05 & 0.08 & * \\
\hline Leisure time is very important, \% & 0.19 & 0.20 & 0.05 & 0.85 & \\
\hline Health is very important, \% & 0.93 & 0.88 & 0.04 & 0.20 & \\
\hline Service to others is very important, \% & 0.19 & 0.19 & 0.04 & 0.92 & \\
\hline Political freedom is very important, \% & 0.73 & 0.28 & 0.03 & 0.00 & $* * *$ \\
\hline Power is very important, $\%$ & 0.32 & 0.26 & 0.02 & 0.01 & ** \\
\hline Religion is very important, \% & 0.06 & 0.00 & 0.03 & 0.11 & \\
\hline Work is very important, \% & 0.80 & 0.63 & 0.02 & 0.00 & $* * *$ \\
\hline Intellectual achievement is very important, \% & 0.24 & 0.33 & 0.03 & 0.02 & ** \\
\hline \multicolumn{6}{|l|}{$\begin{array}{l}\text { Values on Social Norms (Own and Perceptions of } \\
\text { Others): }\end{array}$} \\
\hline Not paying a fare can be justified to some degree, $\%$ & 0.08 & 0.05 & 0.04 & 0.48 & \\
\hline Shirking at work can be justified to some degree, \% & 0.23 & 0.07 & 0.03 & 0.00 & $* * *$ \\
\hline Accepting a bribe can be justified to some degree, \% & 0.19 & 0.06 & 0.03 & 0.00 & *** \\
\hline $\begin{array}{l}\text { Other people think that avoiding to pay a fare can } \\
\text { be justified to some degree, \% }\end{array}$ & 0.15 & 0.18 & 0.04 & 0.47 & \\
\hline $\begin{array}{l}\text { Other people think that shirking at work can be } \\
\text { justified to some degree, \% }\end{array}$ & 0.24 & 0.15 & 0.03 & 0.02 & $* *$ \\
\hline $\begin{array}{l}\text { Other people think that accepting a bribe can be } \\
\text { justified to some degree, } \%\end{array}$ & 0.21 & 0.16 & 0.03 & 0.21 & \\
\hline \multicolumn{6}{|l|}{ Trust: } \\
\hline Most people can be trusted, \% & 0.56 & 0.54 & 0.10 & 0.79 & \\
\hline Have a lot of trust in family members, \% & 0.96 & 0.92 & 0.05 & 0.48 & \\
\hline Have a lot of trust in friends, \% & 0.58 & 0.58 & 0.14 & 0.98 & \\
\hline Have a lot of trust in colleagues, $\%$ & 0.38 & 0.33 & 0.07 & 0.46 & \\
\hline Have a lot of trust or some trust in businessmen, \% & 0.71 & 0.46 & 0.08 & 0.02 & ** \\
\hline Have a lot of trust or some trust in subordinates, \% & 0.95 & 0.83 & 0.04 & 0.02 & ** \\
\hline $\begin{array}{l}\text { Have a lot of trust or some trust in other people from town, } \\
\%\end{array}$ & 0.42 & 0.50 & 0.06 & 0.29 & \\
\hline Have a lot of trust or some trust in compatriots, \% & 0.31 & 0.38 & 0.07 & 0.34 & \\
\hline Have a lot of trust or some trust in foreigners, \% & 0.29 & 0.38 & 0.11 & 0.39 & \\
\hline Have a lot of trust or some trust in local gvmt officials, \% & 0.69 & 0.59 & 0.04 & 0.07 & * \\
\hline $\begin{array}{l}\text { Have a lot of trust or some trust in regional gvmt officials, } \\
\%\end{array}$ & 0.68 & 0.64 & 0.05 & 0.43 & \\
\hline $\begin{array}{l}\text { Have a lot of trust or some trust in central gvmt officials, } \\
\%\end{array}$ & 0.75 & 0.75 & 0.03 & 0.99 & \\
\hline
\end{tabular}


Table 1 (continued)

\begin{tabular}{|c|c|c|c|c|c|}
\hline & $\begin{array}{c}\text { Entrepre- } \\
\text { neurs } \\
\text { Mean }\end{array}$ & $\begin{array}{c}\text { Non- } \\
\text { entrepre } \\
\text { neurs } \\
\text { Condi- } \\
\text { tional } \\
\text { mean }\end{array}$ & & & \\
\hline \multicolumn{6}{|l|}{ Institutional Environment: } \\
\hline People in your town are favorable towards entrepreneurs, \% & 0.68 & 0.60 & 0.08 & 0.33 & \\
\hline Local government is favorable towards entrepreneurs, \% & 0.82 & 0.70 & 0.03 & 0.00 & $* * *$ \\
\hline Regional government is favorable towards entrepreneurs, \% & 0.78 & 0.76 & 0.04 & 0.74 & \\
\hline Central government is favorable towards entrepreneurs, \% & 0.81 & 0.90 & 0.05 & 0.10 & * \\
\hline Private entrepreneurs pay bribes to avoid regulations, \% & 0.50 & 0.54 & 0.05 & 0.57 & \\
\hline Private entrepreneurs pay bribes to change rules, \% & 0.40 & 0.50 & 0.11 & 0.39 & \\
\hline Are businessmen subject to theft of property, \% & 0.70 & 0.98 & 0.14 & 0.08 & $*$ \\
\hline Go to court against a business relation if cheated, \% & 0.90 & 0.88 & 0.02 & 0.48 & \\
\hline Go to court against a government official if abused, \% & 0.80 & 0.73 & 0.01 & 0.00 & $* * *$ \\
\hline $\begin{array}{l}\text { It is relatively easy to find money to start a business in } \\
\text { town, \% }\end{array}$ & 0.38 & 0.26 & 0.09 & 0.28 & \\
\hline \multicolumn{6}{|l|}{ Very serious problem for business: } \\
\hline High taxes, \% & 0.12 & 0.16 & 0.02 & 0.17 & \\
\hline Complicated tax rules and hard tax forms, \% & 0.10 & 0.28 & 0.02 & 0.00 & $* * *$ \\
\hline Competition, \% & 0.10 & 0.36 & 0.04 & 0.00 & $* * *$ \\
\hline Rackets, \% & 0.10 & 0.43 & 0.03 & 0.00 & $* * *$ \\
\hline Inflation and macroeconomic instability, \% & 0.12 & 0.39 & 0.04 & 0.00 & $* * *$ \\
\hline Poor functioning of courts, \% & 0.15 & 0.38 & 0.07 & 0.01 & $* *$ \\
\hline Difficulty of raising outside finance, $\%$ & 0.25 & 0.42 & 0.05 & 0.01 & $* *$ \\
\hline Government administrative regulations, \% & 0.19 & 0.26 & 0.06 & 0.35 & \\
\hline Unequal treatment of similar businesses by bureaucrats, \% & 0.08 & 0.28 & 0.03 & 0.00 & $* * *$ \\
\hline Corruption, \% & 0.17 & 0.48 & 0.09 & 0.01 & $* *$ \\
\hline Crime, \% & 0.09 & 0.45 & 0.04 & 0.00 & $* * *$ \\
\hline Bad public infrastructure, \% & 0.04 & 0.26 & 0.03 & 0.00 & $* * *$ \\
\hline Poor public goods provision, $\%$ & 0.06 & 0.26 & 0.02 & 0.00 & $* * *$ \\
\hline Non-transparent "rules of the game", \% & 0.21 & 0.29 & 0.07 & 0.30 & \\
\hline
\end{tabular}


Table 2. Entrepreneurship and Entrepreneurial Experience

\begin{tabular}{|c|c|c|c|c|}
\hline \multicolumn{5}{|c|}{ Dependent variable } \\
\hline & Entreprenes & hip indicator & riable, Probit & $\begin{array}{c}\text { Years as } \\
\text { entrepreneur, } \\
\text { OLS }\end{array}$ \\
\hline Father had higher education & $\begin{array}{l}0.018 \\
{[0.046]}\end{array}$ & $\begin{array}{l}0.009 \\
{[0.023]}\end{array}$ & $\begin{array}{l}0.005 \\
{[0.020]}\end{array}$ & $\begin{array}{l}0.564 \\
{[0.282]^{*}}\end{array}$ \\
\hline Father was a boss or director & $\begin{array}{l}0.06 \\
{[0.036]^{*}}\end{array}$ & $\begin{array}{l}0.011 \\
{[0.025]}\end{array}$ & $\begin{array}{l}0.011 \\
{[0.022]}\end{array}$ & $\begin{array}{l}0.111 \\
{[0.445]}\end{array}$ \\
\hline Mother was a boss or director & $\begin{array}{l}0.07 \\
{[0.045]}\end{array}$ & $\begin{array}{l}0.091 \\
{[0.059]}\end{array}$ & $\begin{array}{l}0.081 \\
{[0.059]}\end{array}$ & $\begin{array}{l}0.498 \\
{[0.337]}\end{array}$ \\
\hline Mother was a party member & $\begin{array}{l}-0.047 \\
{[0.012]^{* * *}}\end{array}$ & $\begin{array}{l}-0.019 \\
{[0.012]}\end{array}$ & $\begin{array}{l}-0.021 \\
{[0.012]^{*}}\end{array}$ & $\begin{array}{l}-0.467 \\
{[0.120]^{* * *}}\end{array}$ \\
\hline Family members entrepreneurs & $\begin{array}{l}0.041 \\
{[0.006]^{* * *}}\end{array}$ & $\begin{array}{l}0.013 \\
{[0.007]^{*}}\end{array}$ & $\begin{array}{l}0.012 \\
{[0.007]^{*}}\end{array}$ & $\begin{array}{l}0.566 \\
{[0.112]^{* * *}}\end{array}$ \\
\hline $\begin{array}{l}\text { Friends entrepreneurs (from } \\
\text { the last place of study) }\end{array}$ & $\begin{array}{l}0.036 \\
{[0.008]^{* * *}}\end{array}$ & $\begin{array}{l}0.029 \\
{[0.008]^{* * *}}\end{array}$ & $\begin{array}{l}0.031 \\
{[0.010]^{* * *}}\end{array}$ & $\begin{array}{l}0.564 \\
{[0.094]^{* * *}}\end{array}$ \\
\hline Cognitive test score & $\begin{array}{l}0.004 \\
{[0.011]}\end{array}$ & $\begin{array}{l}0.003 \\
{[0.005]}\end{array}$ & $\begin{array}{l}0.004 \\
{[0.005]}\end{array}$ & $\begin{array}{l}0.031 \\
{[0.059]}\end{array}$ \\
\hline Height & $\begin{array}{l}0.003 \\
{[0.000]^{* * *}}\end{array}$ & $\begin{array}{l}0.001 \\
{[0.001]^{* *}}\end{array}$ & $\begin{array}{l}0.001 \\
{[0.000]^{* *}}\end{array}$ & $\begin{array}{l}0.016 \\
{[0.011]}\end{array}$ \\
\hline Risk-loving & & $\begin{array}{l}0.077 \\
{[0.007]^{* * *}}\end{array}$ & $\begin{array}{l}0.078 \\
{[0.006]^{* * *}}\end{array}$ & $\begin{array}{l}0.661 \\
{[0.141]^{* * *}}\end{array}$ \\
\hline $\begin{array}{l}\text { Top } 10 \% \text { in secondary school } \\
\text { (self reported) }\end{array}$ & & $\begin{array}{l}-0.007 \\
{[0.010]}\end{array}$ & $\begin{array}{l}-0.007 \\
{[0.010]}\end{array}$ & $\begin{array}{l}-0.012 \\
{[0.118]}\end{array}$ \\
\hline Greed & & $\begin{array}{l}0.142 \\
{[0.028]^{* * *}}\end{array}$ & $\begin{array}{l}0.141 \\
{[0.027]^{* * *}}\end{array}$ & $\begin{array}{l}1.329 \\
{[0.216]^{* * *}}\end{array}$ \\
\hline $\begin{array}{l}\text { City population perceived } \\
\text { favorable towards entrepreneurs }\end{array}$ & & & $\begin{array}{l}0.009 \\
{[0.008]}\end{array}$ & $\begin{array}{l}0.144 \\
{[0.106]}\end{array}$ \\
\hline $\begin{array}{l}\text { Government perceived } \\
\text { favorable towards entrepreneurs }\end{array}$ & & & $\begin{array}{l}0 \\
{[0.004]}\end{array}$ & $\begin{array}{l}-0.174 \\
{[0.040]^{* * *}}\end{array}$ \\
\hline $\begin{array}{l}\text { Observations } \\
\text { R-squared }\end{array}$ & 851 & 843 & 802 & $\begin{array}{l}785 \\
0.2\end{array}$ \\
\hline
\end{tabular}


Table 3. Failed and would be entrepreneurs and entrepreneur by opportunity or necessity .

\begin{tabular}{|c|c|c|c|c|c|c|}
\hline & \multicolumn{4}{|c|}{ Probit } & \multicolumn{2}{|c|}{ Multinomial logit } \\
\hline & $\begin{array}{l}\text { Was } \\
\text { entrepreneur }\end{array}$ & $\begin{array}{l}\text { Thought } \\
\text { about } \\
\text { entrepre } \\
\text { neurship }\end{array}$ & $\begin{array}{c}\text { Entrepreneur } \\
\text { by } \\
\text { opportunity }\end{array}$ & $\begin{array}{c}\text { Entrepreneur } \\
\text { by } \\
\text { necessity }\end{array}$ & $\begin{array}{c}\text { Entrepreneur } \\
\text { by } \\
\text { opportunity }\end{array}$ & $\begin{array}{c}\text { Entrepreneur } \\
\text { by } \\
\text { necessity }\end{array}$ \\
\hline Father had higher education & $\begin{array}{l}0.012 \\
{[0.030]}\end{array}$ & $\begin{array}{l}-0.003 \\
{[0.081]}\end{array}$ & $\begin{array}{l}0.02 \\
{[0.035]}\end{array}$ & $\begin{array}{l}-0.006 \\
{[0.002]^{* * *}}\end{array}$ & $\begin{array}{l}0.005 \\
{[0.010]}\end{array}$ & $\begin{array}{l}-0.004 \\
{[0.001]^{* * *}}\end{array}$ \\
\hline Father was a boss or director & $\begin{array}{l}0.007 \\
{[0.026]}\end{array}$ & $\begin{array}{l}0.006 \\
{[0.064]}\end{array}$ & $\begin{array}{l}-0.001 \\
{[0.009]}\end{array}$ & $\begin{array}{l}0.006 \\
{[0.007]}\end{array}$ & $\begin{array}{l}0.001 \\
{[0.006]}\end{array}$ & $\begin{array}{l}0.001 \\
{[0.004]}\end{array}$ \\
\hline Mother was a boss or director & $\begin{array}{l}0.008 \\
{[0.066]}\end{array}$ & $\begin{array}{l}0.191 \\
{[0.151]}\end{array}$ & $\begin{array}{l}0.101 \\
{[0.106]}\end{array}$ & $\begin{array}{l}-0.008 \\
{[0.002]^{* * *}}\end{array}$ & $\begin{array}{l}0.025 \\
{[0.014]^{*}}\end{array}$ & $\begin{array}{l}-0.007 \\
{[0.005]}\end{array}$ \\
\hline Mother was a party member & $\begin{array}{l}0 \\
{[0.045]}\end{array}$ & $\begin{array}{l}0.093 \\
{[0.069]}\end{array}$ & $\begin{array}{l}-0.014 \\
{[0.011]}\end{array}$ & $\begin{array}{l}0 \\
{[0.005]}\end{array}$ & $\begin{array}{l}-0.013 \\
{[0.012]}\end{array}$ & $\begin{array}{l}-0.003 \\
{[0.003]}\end{array}$ \\
\hline Family members entrepreneurs & $\begin{array}{l}0.03 \\
{[0.023]}\end{array}$ & $\begin{array}{l}0.065 \\
{[0.018]^{* * *}}\end{array}$ & $\begin{array}{l}0.008 \\
{[0.007]}\end{array}$ & $\begin{array}{l}0.003 \\
{[0.001]^{* * *}}\end{array}$ & $\begin{array}{l}0.004 \\
{[0.004]}\end{array}$ & $\begin{array}{l}0.002 \\
{[0.001]^{* * *}}\end{array}$ \\
\hline $\begin{array}{l}\text { Friends entrepreneurs (from } \\
\text { the last place of study) }\end{array}$ & $\begin{array}{l}0.037 \\
{[0.010]^{* * *}}\end{array}$ & $\begin{array}{l}0.078 \\
{[0.023]^{* * *}}\end{array}$ & $\begin{array}{l}0.029 \\
{[0.005]^{* * *}}\end{array}$ & $\begin{array}{l}0.005 \\
{[0.002]^{* *}}\end{array}$ & $\begin{array}{l}0.016 \\
{[0.005]^{* * *}}\end{array}$ & $\begin{array}{l}0.004 \\
{[0.002]^{* *}}\end{array}$ \\
\hline Cognitive test score & $\begin{array}{l}-0.004 \\
{[0.016]}\end{array}$ & $\begin{array}{l}0.005 \\
{[0.013]}\end{array}$ & $\begin{array}{l}0.001 \\
{[0.003]}\end{array}$ & $\begin{array}{l}0.002 \\
{[0.002]}\end{array}$ & $\begin{array}{l}0.001 \\
{[0.001]}\end{array}$ & $\begin{array}{l}0.001 \\
{[0.001]^{*}}\end{array}$ \\
\hline Height & $\begin{array}{l}-0.006 \\
{[0.001]^{* * *}}\end{array}$ & $\begin{array}{l}0.003 \\
{[0.002]}\end{array}$ & $\begin{array}{l}0 \\
{[0.000]}\end{array}$ & $\begin{array}{l}0 \\
{[0.000]}\end{array}$ & $\begin{array}{l}0 \\
{[0.000]}\end{array}$ & $\begin{array}{l}0 \\
{[0.000]}\end{array}$ \\
\hline Risk-loving & $\begin{array}{l}0.038 \\
{[0.039]}\end{array}$ & $\begin{array}{l}-0.005 \\
{[0.028]}\end{array}$ & $\begin{array}{l}0.053 \\
{[0.009]^{* * *}}\end{array}$ & $\begin{array}{l}0.011 \\
{[0.004]^{* * *}}\end{array}$ & $\begin{array}{l}0.046 \\
{[0.008]^{* * *}}\end{array}$ & $\begin{array}{l}0.012 \\
{[0.003]^{* * *}}\end{array}$ \\
\hline $\begin{array}{l}\text { Top } 10 \% \text { in secondary school } \\
\text { (self reported) }\end{array}$ & $\begin{array}{l}0.119 \\
{[0.053]^{* *}}\end{array}$ & $\begin{array}{l}-0.018 \\
{[0.017]}\end{array}$ & $\begin{array}{l}0.003 \\
{[0.009]}\end{array}$ & $\begin{array}{l}0.003 \\
{[0.004]}\end{array}$ & $\begin{array}{l}-0.004 \\
{[0.005]}\end{array}$ & $\begin{array}{l}-0.001 \\
{[0.003]}\end{array}$ \\
\hline Greed & $\begin{array}{l}0.016 \\
{[0.029]}\end{array}$ & $\begin{array}{l}0.032 \\
{[0.047]}\end{array}$ & $\begin{array}{l}0.1 \\
{[0.023]^{* * *}}\end{array}$ & $\begin{array}{l}0.026 \\
{[0.004]^{* * *}}\end{array}$ & $\begin{array}{l}0.043 \\
{[0.009]^{* * *}}\end{array}$ & $\begin{array}{l}0.015 \\
{[0.003]^{* * *}}\end{array}$ \\
\hline $\begin{array}{l}\text { City population perceived } \\
\text { favorable towards entrepreneurs }\end{array}$ & $\begin{array}{l}0.009 \\
{[0.027]}\end{array}$ & $\begin{array}{l}0.015 \\
{[0.049]}\end{array}$ & $\begin{array}{l}0.005 \\
{[0.008]}\end{array}$ & $\begin{array}{l}0.001 \\
{[0.002]}\end{array}$ & $\begin{array}{l}0.005 \\
{[0.007]}\end{array}$ & $\begin{array}{l}0.002 \\
{[0.000]^{* * *}}\end{array}$ \\
\hline $\begin{array}{l}\text { Government perceived } \\
\text { favorable towards entrepreneurs }\end{array}$ & $\begin{array}{l}-0.048 \\
{[0.006]^{* * *}}\end{array}$ & $\begin{array}{l}-0.014 \\
{[0.017]}\end{array}$ & $\begin{array}{l}-0.004 \\
{[0.001]^{* * *}}\end{array}$ & $\begin{array}{l}-0.001 \\
{[0.001]}\end{array}$ & $\begin{array}{l}0 \\
{[0.002]}\end{array}$ & $\begin{array}{l}0 \\
{[0.001]}\end{array}$ \\
\hline Observations & 456 & 392 & 718 & 718 & 782 & 782 \\
\hline
\end{tabular}

Robust standard errors in brackets 
Table 4.. Enterprise growth and Expansion.

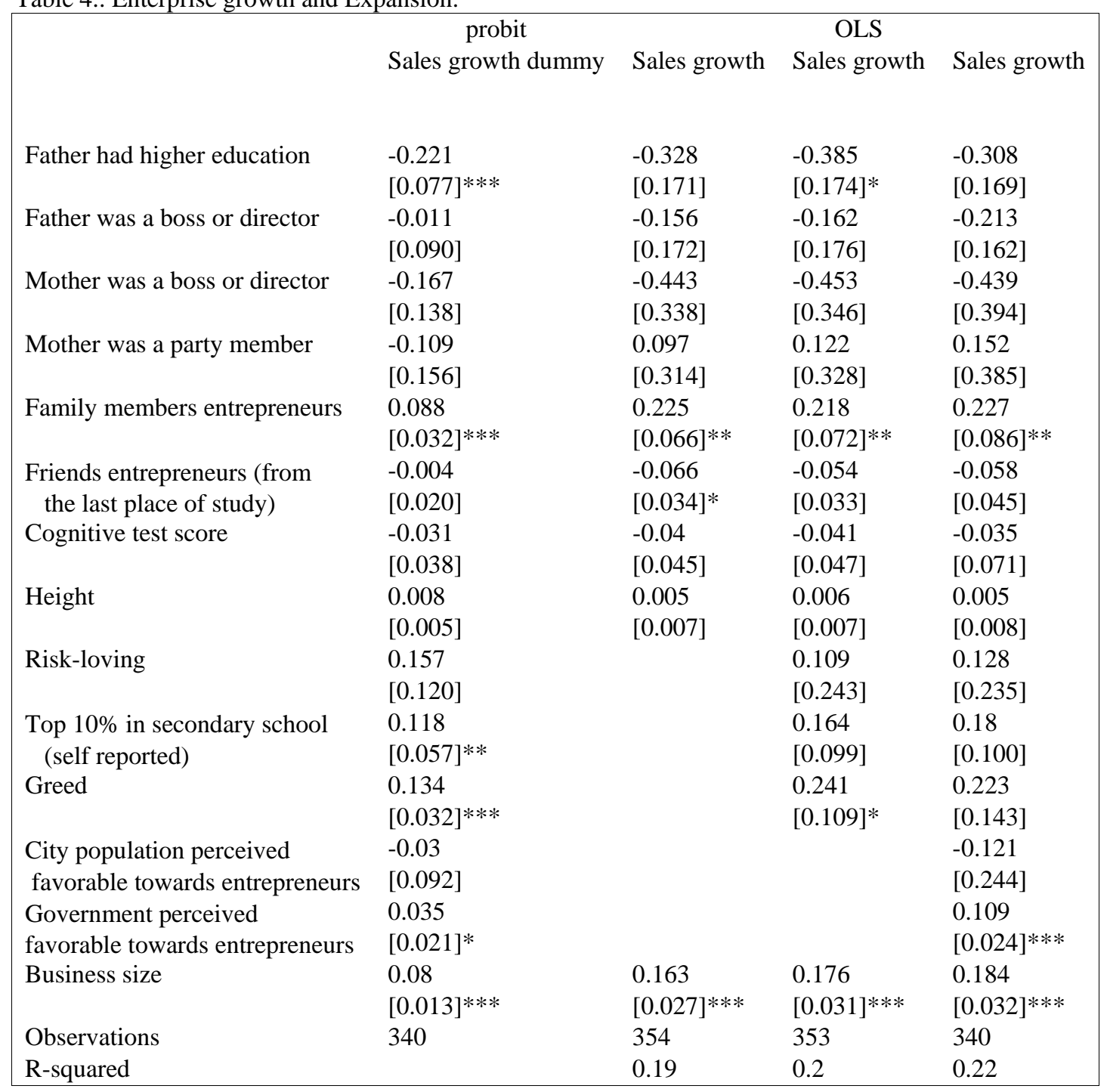


Table 5. Financing Chinese entrepreneurs

Table 5 a The main source of financing for start-ups and for expansions of existing businesses

\begin{tabular}{|l|c|c|}
\hline & Start-ups (414 obs.) & Expansions (198 obs.) \\
\hline Personal savings / retained earnings & $57 \%$ & $70 \%$ \\
Loan or investment from relatives & $12 \%$ & $5 \%$ \\
Loan or investment from friends & $6 \%$ & $4 \%$ \\
Bank credit & $4 \%$ & $13 \%$ \\
Government subsidy or grant & $0 \%$ & $1 \%$ \\
Other sources & $21 \%$ & $8 \%$ \\
\hline
\end{tabular}

Table 5b

What is the main reason why your thoughts did not realize in an actual business?

[Among respondents who seriously thought of becoming an entrepreneur but did not actually start a business (84 obs.)]

Did not find money

Did not find a good project

Too much risk

For personal reasons

Bureaucratic constraints and corruption

I had / found job that brought me more money

Other

\section{Table 5c}

\begin{tabular}{|l|r|}
\hline \multicolumn{2}{|c|}{$\begin{array}{c}\text { What is the main reason why you have not ever seriously } \\
\text { thought of becoming an entrepreneur? }\end{array}$} \\
[Among respondents who have never seriously thought of \\
becoming an entrepreneur (402 obs.)] \\
\hline Would not have been about to find money & $29 \%$ \\
Do not have appropriate skills & $24 \%$ \\
Satisfied with current job & $21 \%$ \\
Entrepreneurship is too risky & $15 \%$ \\
For personal reasons & $4 \%$ \\
Would not like entrepreneurship as an activity & $4 \%$ \\
Unfavorable economic environment & $3 \%$ \\
Entrepreneurship is not prestigious & $0 \%$ \\
\hline
\end{tabular}

